\title{
REKAYASA LAMPU LED CELUP UNTUK PERIKANAN BAGAN APUNG DI PERAIRAN PATEK KABUPATEN ACEH JAYA PROPINSI ACEH
}

\author{
SUBMERGED LED LIGHTS ENGINEERING FOR LIFTNET FISHERIES \\ IN PATEK WATERS ACEH JAYA DISTRICT ACEH PROVINCE
}

\author{
Taufiq $^{1}$, Wazir Mawardi ${ }^{2}$, Mulyono S. Baskoro ${ }^{2}$ Zulkarnain $^{2}$ \\ ${ }^{1}$ Program Studi Teknologi Perikanan Laut, Sekolah Pascasarjana \\ ${ }^{2}$ Departemen Pemanfaatan Sumberdaya Perikanan \\ Fakultas Perikanan dan Ilmu Kelautan, Institut Pertanian Bogor \\ Korespondensi : afiq.mbo13@gmail.com
}

\begin{abstract}
Fishery potential utilization in the waters of Aceh Jaya was dependent on fishing technology and still limited.The type of fishing gears which used in Aceh Jaya were beach seine, line fishing, gillnet, and liftnet. Liftnet used by Patek fishermen was floating liftnet. Bagan was classified in light fishing. The type of lamps which used by fishermen was fluorescent and set on the surface, whereas the surface lamp was less effective for use. This research used underwater lamp. The aims of this research were to get underwater lamp construction and determine the LED effectiveness. Construction of underwater lamp designed an innovation, that was the dimmed, so that fish which have aggregated by the light would more focus to the liftnet. The research methods were descriptive, fishing gear construction design, experiment or experimental fishing. Underwater lamp lights could help Patek fishermen for fishing and got maximum catches. Total catches by using fluorescent light were $2343 \mathrm{~kg}$. Meanwhile, total catches with underwater lamp were $3779 \mathrm{~kg}$. Fish species that were caught by liftnet were anchovy, peperek, tembang, mackerel, selar, japuh, and layur for 10 trip, 5 trip in the dark and the bright moon. Seen that there were differences of catches amount and composition by using fluorescent lamps and underwater lamp. The results of research it was concluded effective underwater lamp as a tool in fisheries liftnet.
\end{abstract}

Keywords: Aceh Jaya, light emititon diode, lift net, underwater lamp

\begin{abstract}
ABSTRAK
Kegiatan pemanfaatan potensi perikanan tangkap di perairan Aceh Jaya masih banyak tergantung pada teknologi penangkapan ikan masih terbatas. Jenis alat tangkap yang digunakan di Aceh Jaya adalah pukat pantai, pancing, jaring insang, dan bagan. Jenis bagan yang digunakan oleh nelayan patek yaitu bagan apung. Bagan merupakan salah satu perikanan light fishing. Jenis lampu yang digunakan oleh nelayan patek adalah neon yang ditempatkan di permukaan, sedangkan lampu permukaan ini kurang efektif untuk digunakan. Penelitian ini menggunakan lampu LED celup. Tujuan dari penelitian ini adalah mendapatkan konstruksi lampu celup dalam air dan menentukan efektifitas lampu LED celup. Konstruksi lampu LED celup dirancang sebuah inovasi yaitu lampu dapat diredupkan sehingga ikan-ikan yang sudah mendekat ke cahaya sehingga lebih terfokus ke bagan. Metode penelitian ini adalah deskriptif, rancang bangun alat, percobaan atau experimental fishing. Dengan adanya lampu LED celup bisa membantu nelayan patek dalam menangkap ikan dan mendapatkan hasil yang lebih maksimal. Total hasil tangkapan dengan menggunakan lampu neon sebesar $2343 \mathrm{~kg}$. Sedangkan, total hasil tangkapan dengan lampu LED celup adalah sebesar $3779 \mathrm{~kg}$. Jenis ikan yang tertangkap pada alat tangkap bagan yaitu teri, peperek, tembang, kembung, selar, japuh, dan layur selama 10 trip, 5 trip bulan gelap dan bulan terang. Terlihat bahwa ada perbedaan jumlah dan komposisi hasil tangkapan dengan menggunakan lampu neon dan lampu celup. Dari hasil penelitian didapatkan kesimpulan lampu LED celup lebih efektif untuk digunakan sebagai alat bantu pada perikanan bagan.
\end{abstract}

Kata kunci: Aceh Jaya, bagan apung, lampu celup light emition diode, light emition diode 


\section{PENDAHULUAN}

Kondisi sumberdaya perikanan di Kabupaten Aceh Jaya masih dapat dikategorikan perikanan yang baik dan belum banyak dimanfaatkan, karena kurang tesedianya armada perikanan tangkap yang memadai karena nelayan masih banyak menggunakan kapal-kapal yang berukuran kecil. Salah satu lokasi operasi penangkapan ikan di Aceh Jaya adalah perairan Patek. Hasil tangkapan ikan di perairan Patek sebagian besar adalah jenis ikan pelagis kecil seperti ikan teri, kurisi, ekor kuning, selar, kuniran, yang berharga rendah, dibandingkan hasil tangkapan ikan pelagis besar seperti ikan tongkol, tuna, cakalang, yang nilai jualnya lebih tinggi (Nasrudin 2009).

Jenis alat tangkap yang dominan digunakan dalam kegiatan operasi penangkapan ikan di Aceh Jaya diantaranya adalah pukat pantai, pancing, jaring insang, bagan tancap dan bagan apung. Jenis alat tangkapan ikan masih belum memberikan hasil yang optimal. Jenis alat tangkap yang biasa digunakan oleh nelayan Patek adalah bagan apung. Salah satu faktor pendukung keberhasilan perikanan bagan adalah cahaya (Sudirman \& Nessa 2011). Cahaya merupakan alat bantu untuk mengumpulkan ikan di daerah cakupan alat tangkap sehingga ikan-ikan dapat ditangkap (Notanubun \& Patty 2010).

Penelitian mengenai bagan telah dilakukan oleh beberapa peneliti seperti sumber cahaya sebagai alat bantu pada bagan. Bermacam sumber cahaya yang digunakan pada bagan diantaranya lampu petromaks. Setelah pencabutan subsidi bahan bakar minyak tanah pada tahun 2010 lampu petromaks di nilai tidak lagi ekonomis. Nelayan bagan beralih ke lampu neon dengan menggunakan bahan bakar sumber energi listrik yang di hasilkan dari generator set (genset). Lampu petromaks dan lampu neon di operasikan di atas permukaan air. Lampu permukaan kurang efektif karena terjadinya pemantulan cahaya yang di akibatkan oleh permukaan air (Syafrie 2012).

Penelitian lainpun telah dilakukan mengenai aplikasi lampu LED (Light Emitting Diode) pada pengoperasian bagan tancap. Penelitian tersebut merancang konstruksi lampu LED celup dengan dimensi yang masih terbatas. Peneliti juga menyimpulkan penggunaan lampu LED celup dapat memberikan hasil yang lebih banyak dibandingkan lampu yang dioperasikan di atas permukaan air. Jenis lampu yang digunakan tipe LED ultra bright white $5 \mathrm{~mm}$ (3.2-3.4 V dan 0.04 A) (Thenu 2015). Penelitian ini merupakan penelitian lanjutan dengan merancang kembali kostruksi lampu dengan dimensi lebih panjang dan di rancang inovasi pada lampu yaitu sistem penurunan intensitas cahaya (sistem peredupan). Jenis lampu LED yang digunakan tipe LED super bright blue $5 \mathrm{~mm}$ (3.2-3.4 $\mathrm{V}$ dan $0.02 \mathrm{~A})$, jenis lampu yang digunakan dalam penelitian ini lebih murah dibandingkan LED ultra bright white $5 \mathrm{~mm}$. Tujuan dari penelitian ini adalah mendapatkan konstruksi dan menentukan efektivitas lampu celup dalam air dengan menggunakan lampu LED. Manfaat penelitian ini adalah dapat memberikan masukan kepada nelayan Aceh Jaya dalam meningkatkan produksi perikanan bagan apung dan menghematkan biaya operasional serta memberikan informasi dasar untuk pengembangan lampu LED celup.

\section{METODE PENELITIAN}

Penelitian ini dilakukan dalam dua tahap. Tahap pertama penelitian laboratorium dengan merancang, membuat dan ujicoba alat dilakukan pada bulan JuliDesember 2014 bertempat di Workshop Devisi Kapal dan Transportasi Perikanan, Departemen Pemanfaatan Sumberdaya Perikanan, Fakultas Perikanan dan Ilmu Kelautan, Institut Pertanian Bogor.

Tahap kedua, penelitian lapangan ujicoba alat pada saat operasi penangkapan dilakukan pada bulan Januari-Februari 2015. Tahap ini dilakukan ujicoba lampu LED celup yang sudah dirancangan dengan menggunakan alat tangkap bagan apung diperairan Patek, Kabupaten Aceh Jaya, Propinsi Aceh.

Alat yang digunakan dalam perancangan lampu LED celup adalah alat ukur panjang, gergaji besi, spidol, solder, bor listrik, ATK, Avometer, luxmeter, dan bagan apung.

Bahan yang digunakan dalam perancangan dan pembuatan lampu LED celup adalah lampu kamera, LED super bright blue $5 \mathrm{~mm}$, pipa PVC (polyvinil chloride), accu, power supply, mangkok plastik, resistor, cat pilox, timah solder, mata bor, kabel lisrik, dimmer DC, lem akrilik (acrylic polycarbonat), dan tabung akrilik. 


\section{Metode pengumpulan data}

Metode penelitian yang digunakan dalam penelitian ini adalah rancang bangun alat, experimental fishing, dan pengumpulan data dilakukan menggunakan metode deskriptif komparatif dengan mengumpul jenis data yaitu data primer dan data sekunder. Data primer dikumpulkan dengan cara melakukan pengukuran langsung dengan parameter terkait seperti, pengukuran iluminasi cahaya, biaya operasional, dan waktu operasi penangkapan serta jenis dan komposisi hasil tangkapan ikan di perairan Patek. Sedangkan, data sekunder dikumpulkan dengan cara studi literatur yang menyangkut dengan penelitian ini.

\section{Penelitian di laboratorium}

\section{Konstruksi elektronik lampu LED celup}

Sistem rangkaian lampu merupakan bagian utama dan komponen terpenting dari konstruksi lampu LED celup, banyak hal yang harus dipertimbangkan dan diperhatikan, supaya lampu bisa digunakan dan bertahan didalam air dengan baik. Hal ini untuk membuat saat pengoperasian lampu di dalam laut, tahan terhadap kerusakan, korosi maupun tebakar. Selanjutnya pada bagian rangkaian lampu, material yang digunakan dibuat tahan karat, setiap sambungan dengan solder dilapisi lem, sedangkan pada bagian lampu LED SPB $5 \mathrm{~mm}$ dan resistor dengan menggunakan rangkaian paralel. Di Aceh Jaya belum ada yang menggunakan lampu jenis ini sebagai alat bantu pada alat tangkap bagan.

Tahap pertama, lampu LED yang digunakan yaitu tipe LED super bright blue $5 \mathrm{~mm}, 3.2 \mathrm{~V}-3.4 \mathrm{~V}$ dan 0.02 A. Lampu LED jenis ini dipilih karena harganya lebih murah, mudah dikondisikan, efesiensi yang tinggi, tidak mudah pecah, daya tahan lebih kurang 50.000 jam, bebas merkuri ataupun hologen (Nielsen 2003). Tinggi rendahnya intensitas cahaya akan mempengaruhi jarak ikan berkumpul dari sumber cahaya. Intensitas cahaya yang digunakan pada bagan berpengaruh terhadap hasil tangkapan, dimana semakin tinggi intensitas semakin banyak hasil tangkapan. Intensitas cahaya yang paling tinggi terdapat pada warna biru. Warna biru ini memiliki gelombang cahaya pendek dan spektrum cahayanya lebih panjang jadi jangkaunnya lebih luas dan intensitasnya lebih tinggi serta warna biru lebih banyak disukai oleh banyak jenis ikan (Sudirman \& Mallawa 2004). Penangkapan ikan-ikan predator seperti japuh, dan pepetek lebih efektif dengan menggunakan lampu warna biru (Gustaman et al. 2012).

Tahap kedua, menentukan rangkaian listrik yang digunakan pada saat merangkai lampu LED celup yaitu rangkaian paralel. Rangkaian listrik paralel memiliki keuntungan seperti beban satu tidak mempengaruhi beban lain artinya apabila satu lampu putus maka lampu lain tetap menyala dan tegangan yang diterima setiap beban semua sama. Sedangkan, kelemahannya adalah terlalu boros menghabiskan kabel pada saat merangkai lampu (Wardana et al. 2011).

Tahap ketiga, menentukan resistor yang digunakan dalam rangkaian lampu. Resistor yang digunakan dalam rangkaian ini adalah $47 \mathrm{Ohm}$ - 2 Watt. Hasil ini didapatkan berdasarkan persamaan dibawah. Resistor adalah komponen dasar elektronika yang digunakan untuk membatasi jumlah arus yang mengalir dalam satu rangkaian. Kegunaan daripada resistor ini adalah untuk menahan arus sehingga arus yang masuk ke rangkaian LED lebih teratur selain itu apabila lampu terbakar maka lampu yang terbakar 1 rangkaian saja, sedangakan lampu pada rangkaian lain tetap menyala. Jika diketahui tahanan resistor (Ohm) yang digunakan maka akan diketahui juga berapa Arus (A) dan daya (W).

$$
\begin{gathered}
\mathrm{R}=\frac{V_{a c c u}-V_{L E D}}{I_{L E D}}=\text { Ohm; } \\
\mathrm{I}_{\mathrm{LED}}=\frac{V_{a c c u}-V_{L E D}}{R_{L E D}}=\text { Ampare; } \\
\mathrm{I}_{\text {total }}=\text { total LED } \times \mathrm{I}_{\mathrm{LED}}=\mathrm{A}_{\text {total }} ; \text { dan } \\
\mathrm{P}_{\mathrm{LED}}=\mathrm{V}_{\mathrm{LED}} \times \mathrm{I}_{\mathrm{LED}}=\mathrm{W}_{\mathrm{LED}} \\
\mathrm{P}_{\text {total }}=\mathrm{P}_{\mathrm{LED}} \times \text { Total } \mathrm{LED}=\mathrm{W}_{\text {total }}
\end{gathered}
$$

Keterangan :

$\mathrm{R}$ : Tahanan resistor $(\mathrm{Ohm})$

$\mathrm{V}_{\text {accu }}$ : Tegangan Sumber (V)

$\mathrm{V}_{\mathrm{LED}}$ : Tegangan LED (V)

$\mathrm{I}_{\mathrm{LED}}$ : Arus LED (A)

$\mathrm{P}_{\text {LED }}$ : Daya LED $(\mathrm{W})$

Tahap keempat, merancang sistem penurunan intensitas cahaya (sistem peredupan) pada lampu. Sistem peredupan pada lampu dengan menggunakan dimmer DC. Merancang sistem peredupan 
ini bertujuan pada saat lampu sudah dinyalakan dapat diredupkan, sehingga ikan-ikan yang sudah terkumpul di area lampu lebih terkonsentrasi pada area alat tangkap. Ketika ikan-ikan sudah terkumpul di atas jaring bagan dilakukan pengangkatan jaring, maka disini tidak perlu lagi menggunakan lampu hauling.

\section{Mendesain bentuk konstruksi lampu LED celup (underwater lamp)}

Merancang dan mengkonstruksi bentuk lampu LED celup sangat perlu diperhatikan dalam menentukan bentuk dan bahan yang digunakan dalam pembuatannya. Tahap pertama, bentuk konstruksi lampu LED celup dirancang berbentuk tabung atau silinder vertikal. Bentuk tabung memiliki ruang yang lebih luas dibandingkan bentuk yang lain. Bentuk tabung atau silinder vertikal adalah bangun ruang tiga dimensi yang dibentuk oleh dua buah lingkaran identik yang sejajar dan sebuah persegi panjang yang mengelilingi kedua lingkaran tersebut (Firdawati 2011). Bentuk tabung sangat sesuai untuk digunakan pada konstruksi perancangan lampu LED celup, karena dapat menerangi sekeliling secara merata. Bahan yang digunakan adalah pipa PVC berdiameter dan pada bagian bawah konstruksi dirancang dengan bentuk setengah kerucut ke bawah dengan menggunakan bahan mangkok plastik, sehingga dapat menerangi kedasar perairan.

Tahap kedua, merancang pemberat yang diletakkan pada bagian tengah lampu. Bahan yang digunakan adalah pemberat batangan seberat $12 \mathrm{~kg}$, lalu dicor dengan semen pada pipa PVC $\varnothing 3$ inchi, panjang $80 \mathrm{~cm}$. Tujuan penambahan pemerat ini agar ketika lampu dimasukkan kedalam perairan tidak tebawa arus dan tidak membuat ikan menjadi takut sehingga kabur dari area sumber cahaya.

Tahap ketiga, membuat tabung pelindung lampu dengan menggunakan tabung akrilik bening. Akrilik selain bersifat tenggelam di air dan juga kuat serta tidak mengurangi tingkat penerangan dibandingkan kaca dan PVC bening. Bahan akrilik memiliki daya kekuatan tekan sebesar 1238,65 kgf dan memiliki nilai modulus of elastisity (MOE) sebesar 130.49$140.01 \mathrm{kgf} / \mathrm{cm}$. Nilai tersebut menunjukan jauh lebih tinggi dari tekanan air.

Pada kedalaman 20 meter (Yulianto 2015). Modulus of Elastisity (MOE) adalah suatu nilai yang konstan dan merupakan perbandingan antara tegangan dan regangan dibawah batah proporsi. Tegangan didefinisikan sebagai distribusi gaya per unit luas, sedangkan regangan adalah perubahan panjang per unit bahan (Haygreen \& Bowyer 1993). Tabung ini ditutup pada bagian bawah dengan lem khusus akrilik dan dibuat penutup atas tabung, sehingga tabung bisa di buka-tutup dan lampu bisa di keluar masukkan. Setalah semuanya dibuat akan diujicoba kedap air, apabila tabung tidak kemasukan air maka dianggap berhasil. Bentuk rancang konstruksi lampu LED celup terdapat pada Gambar 1.

\section{Pembuatan lampu LED celup dalam air (underwater lamp)}

Tahapan dan proses pembuatan lampu LED celup adalah dengan di dokumentasikan secara terstruktur mulai dari awal hingga selesai. Analisis yang digunakan dalam proses pembuatan lampu celup adalah analisis deskriptif yaitu menjabarkan proses dari pembuatan dan pemilihan bahan yang digunakan, selain itu didukung juga oleh referensi yang ada serta spesifikasi dari bahan material yang digunakan (Sugioyono 2007).

\section{Sistem rangkaian lampu}

Sistem rangkaian lampu merupakan bagian utama dan komponen terpenting dari konstruksi lampu dalam air, jadi banyak yang harus dipertimbangkan dan diperhatikan pada saat pembuatan lampu berlangsung. Tahap pertama, disiapkan pipa PVC $\varnothing 4$ inci, panjang $85 \mathrm{~cm}$. Pipa dibelah menjadi 2 bagian untuk mempermudah pemasangan lampu, kedua permukaan paralon dilubangi menggunakan bor listrik dengan mata bor $4.50 \mathrm{~mm}$, jarak antar lubang $1.50 \times 1.50 \mathrm{~cm}$. Selanjutnya pipa dicat menggunakan cat pilox berwarna perak sehingga dapat memantulkan cahaya. Disiapkan pula mangkok lalu dilakukan seperti halnya paralon (dilubangi dan dicat dengan warna perak). Mangkok ini nantinya dipasang pada bagian bawah paralon.

Tahap kedua adalah melakukan pemasangan lampu LED pada pipa paralon. Rangkaian listrik yang digunakan pada perancangan lampu yaitu rangkaian paralel. LED ditentukan bagian positif-negatifnya terlebih dahulu dengan melihat pada kaki yang panjang sebelah, panjang $(+)$ dan pendek (-) (Setiadi et al. 2012). Lampu LED 
yang dipasang pada pipa setiap 10 LED terdapat 1 resistor. Semua rangkaian lampu disolder supaya lebih aman dan arus yang mengalir tetap stabil. Selanjutnya diberikan anti korosi pada seluruh rangkaian lampu, sehingga rangkaian lampu tahan terhadap korosi. Lampu yang sudah selesai dirangkai dilakukan ujicoba hidup atau tidak. Kalau lampu tidak menyala, maka perlu dicek kembali rangkaian LED. Apabila lampu menyala, maka dianggap selesai dan berhasil pada tahap pembuatan rangkaian lampu. Rangkaian paralel pada lampu LED celup terdapat pada Gambar 2.

\section{Pembuatan tabung pelindung lampu}

Pembuatan tabung pelindung lampu dengan mengunakan bahan akrilik. Tabung yang digunakan dengan ukuran (panjang $100 \mathrm{~cm}, \varnothing 6$ inci, dan ketebalan $5 \mathrm{~mm}$ ). Setelah ditentukan bagian bawah dilakukan penutupan secara pemanen pada bagian bawah dengan menggunakan akrilik, selanjutnya dirancang penutup bagian atas dibuat bisa buka-tutup. Setelah bagian bawah dan atas tabung ditutup dilakukan uji kedap air. Apabila tabung kemasukan air maka tabung diperbaiki kembali sehingga tidak masuk air. Rancangan pembuatan tabung pelindung terdapat pada Gambar 3.

\section{Uji kedap air}

Tabung pelindung diujicobakan atau dimasukkan kedalam air 1-2 $\mathrm{m}$ dalam water tank untuk diuji ada kebocoran atau tidak. Lama perendaman sekitar 1-2 jam, kemudian tabung di angkat ke atas dan dipastikan tidak ada air yang masuk kedalam tabung. Apabila tidak ada air yang masuk maka uji kedap air selasai. Tabung diujicobakan dalam keadaan kosong atau tanpa rangkaian lampu. Lampu yang sudah selesai dirangkai pada paralon, lalu dimasukkan ke dalam tabung pelingdungnya yang sudah teruji kedap air.

\section{Uji sebaran cahaya di udara}

Iluminasi merupakan intensitas penerangan atau kekuatan penerangan. Intensitas penerangan adalah flux cahaya yang jatuh pada suatu permukaan, atau kekuatan cahaya yang dipancarkan dari suatu sumber cahaya. Besarnya diukur dengan satuan candela. Sementara flux cahaya dipancarkan oleh suatu sumber cahaya adalah seluruh jumlah cahaya yang dipancarkan dalam satu detik. Iluminasi cahaya akan turun jika jarak dari sumber cahaya semakin jauh dan apabila cahaya melewati medium air. Mengukur iluminasi cahaya dari suatu sumber cahaya digunakan rumus berikut (Puspito 2008).

$$
\mathrm{E}=\frac{I}{r^{2}}
$$

Keterangan :

E : Iluminasi cahaya (lux);

$I$ : Intensitas cahaya (candela); dan

$r$ : Jarak dari sumber cahaya $(\mathrm{m})$

Prosedur pengukuran iluminasi cahaya di udara untuk mengetahui pola sebaran cahaya lampu LED celup yang dibuat dengan menggunakan luxmeter. Pengukuran cahaya dilakukan pada 2 jenis lampu yaitu lampu LED celup yang sudah dirancang dan lampu neon yang digunakan oleh nelayan sebagai perbandingan. Pengukuran dilakukan secara horizontal dan vertikal pada setiap kelipatan sudut $10^{\circ}$ dengan jarak yang berbeda $50 \mathrm{~cm}, 75$ $\mathrm{cm}, 100 \mathrm{~cm}$, dan $125 \mathrm{~cm}$, pada medium udara. Pengukuran dilakukan pada posisi horizontal dan vertikal terhadap arah lampu. Nilai intensitas cahaya pada setiap sudut pengukuran $10^{\circ}$ dicatat.

Analisis data yang digunakan adalah metode deskriptif komparatif. Mendeskripsikan semua kegiatan mulai dari awal perancangan sampai uji coba alat dalam bentuk kalimat dari tabel dan grafik. Metode komparatif yaitu melakukan perbandingan lampu LED dengan lampu neon (Nikonorov 1975).

\section{Penelitian di Lapangan}

Uji coba lampu LED celup pada saat operasi penangkapan ikan

Penelitian ini dilakukan uji coba pada saat penagkapan ikan dengan tujuan dapat mengetahui kemampuan dari lampu LED celup dalam mengumpulkan dan mengkonsentrasikan ikan-ikan di dalam area jaring bagan. Pengamatan di dalam air dilakukan dengan menggunakan metode pengamatan visual dan melihat komposisi hasil tangkapan bagan. Selanjutnya diamati beberapa variabel pada saat lampu LED celup dalam air dioperasikan diantaranya adalah tingkah laku dan sebaran kawan ikan yang berada di area bagan apung dalam beberapa waktu setting dan hauling, tingkah laku ikan pada saat lampu dilakukan 
peredupan, dan tingkah laku ikan setelah dilakukan hauling. Analisis data mengenai tingkat efektifitas alat dapat dilihat dari total tangkapan per-hauling, komposisi tangkapan, rata-rata tangkapan dengan menggunakan lampu LED celup maupun lampu neon. Kedatangan kawanan ikan disekitar bagan yang diberikan pencahayaan dapat meliputi pola pergerakan dan pada saat pengoperasian bagan di analisis secara deskriptif berdasarkan pengamatan visual untuk kawanan ikan yang terakumulasi berada di area jaring dan di bawah cahaya.

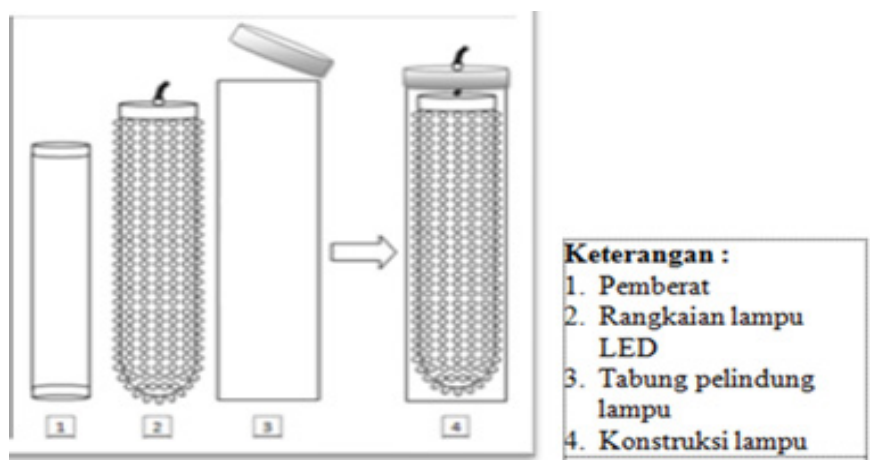

Gambar 1. Rancang konstruksi lampu LED celup

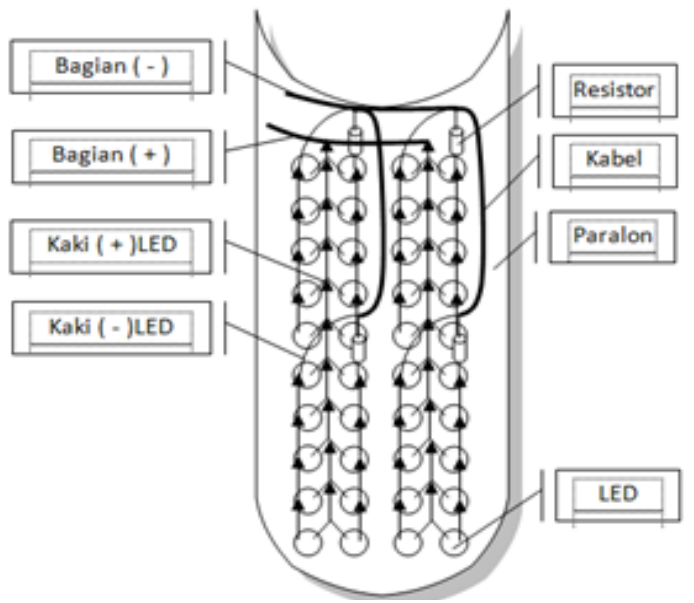

Gambar 2. Rangkaian paralel pada lampu LED celup

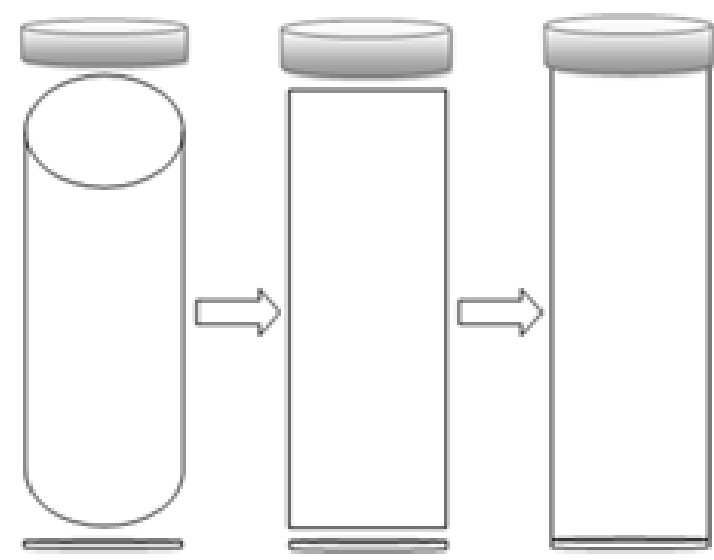

Gambar 3. Rancang pembuatan tabung pelindung lampu 


\section{HASIL DAN PEMBAHASAN}

\section{Rancangan dan konstruksi lampu LED celup}

Perencanaan desain awal untuk penggunaan di dalam air dengan tujuan dapat mengurangi penurunan intensitas cahaya seperti lampu neon yang digunakan pada permukaan disebabkan oleh media rambat cahaya. Oleh karena itu perencanaan pembuatan lampu LED celup sangat perlu juga diperhatikan material dan bahan yang digunakan, karena sangat berpengaruh terhadap konstruksi dari lampu LED celup. Selain itu lampu juga dirancang dengan sebuah inovasi yang dapat mengatur intensitas cahaya sesuai kebutuhan, sehingga nelayan mudah mengoperasikan dan tidak perlu menggunakan lampu hauling lagi. Desain lampu agar cahaya bisa dipancarkan ke segala arah, tujuannya adalah menarik ikan dalam luasan yang seluas-luasnya baik secara horizontal maupun vertikal. Berdasarkan hasil rancangan konstruksi, maka bentuk tabung atau silinder vertikal dan bentuk kerucut dibagian bawah baik untuk digunakan dalam perancangan (Firdawati 2011).

Kelebihan daripada rancangan kostruksi lampu LED celup adalah sebuah inovasi terbaru yang telah disebutkan diatas. Sistem lampu ini terhubung dengan dengan dimmer supaya penurunan intensitas cahaya dapat diatur sesuai kebutuhan, lalu sistem lampu juga terhubung dengan sistem power supply menggunakan sakelar. Sumber energi yang digunakan untuk lampu berasal dari sumber arus yaitu aki, sehingga dapat memudahkan para nelayan dalam mengoperasikannya. Sistem rangkaian pada lampu LED celup terdapat pada Gambar 4.

\section{Sistem rangkaian lampu}

Sistem rangkaian lampu adalah bagian yang sangat penting diperhatikan sehingga lampu LED celup dapat digunakan dengan baik dan tahan lama. Faktor yang penting diperhatikan adalah penggunaan bahan, karena mengingat lampu LED celup ini dioperasikan didalam air, kemungkinan terjadinya kerusakan, korosi dan kebocoran. Pemilihan menjadi salah satu yang harus dipertimbangkan pada saat lampu dirancang.

Lampu hasil rekayasa yang digunakan adalah lampu LED SPB $5 \mathrm{~mm}$ sebanyak 1457 lampu yang dipasang pada pipa PVC dengan rangkaian paralel. Lampu LED yang terpasang terhubung dengan resistor yang berfungsi untuk menahan arus, sehingga arus lebih stabil. Tipe resistor yang digunakan adalah 47 Ohm-2 watt dengan jumlah sebanyak 146. Resistor dihubungkan pada kaki positif lampu dan pada kaki negatif dihubungkan dengan kabel, maka setiap kabel pada bagian positif dijadikan satu begitu juga pada bagian negatifnya. Setelah itu bagian $\left(^{+}\right)$ dan (-) dihubungkan pada dimmer sebagai sistem peredupan pada lampu. Kabel yang terhubung pada dimmer dihubungkan ke power supply dengan sistem sakelar, lalu dihubungkan pada ke aki sebagai sumber daya. Hasil rancangan konstruksi lampu LED celup terdapat pada Gambar 5 dan 6.

\section{Konversi lampu LED dengan lampu neon}

Pengukuran tegangan pada lampu yang dibutuh untuk lampu LED lalu dikonversikan ke lampu neon 45 Watt. Lampu yang digunakan nelayan sebesar 450 watt dengan jumlah lampu 10 unit. Pengukuran ini dilakukan dengan cara mengukur iluminasi cahaya atau tegangan lampu LED lalu dikonversikan ke lampu neon yang nelayan gunakan. Berdasarkan penelitian sebelumnya lampu LED memiliki lifespan lebih dari 35.000 jam, dibandingkan dengan lampu CFL (Compact Flourescent Lamp) yang hanya 6.000 jam. Umumnya ditulis pada kotak lampu CFL, dengan pemakaian 4 jam sehari jam 6 malam - jam 10 malam) lampu CFL tahan lebih dari 4 tahun (4 tahun $\times 365$ hari $\times 4$ jam $=5840$ jam) (Hua and Xing 2013). Berdasarkan hasil penelitian sebelumnya lampu LED 3 watt setara dengan lampu CFL 8 watt. Standar lampu LED memiliki 60-100 lumens (Lumens adalah ukuran cahaya oleh mata manusia yang dapat diterima), sedangkan lampu CFL memiliki 14-17 lumens. Dengan lampu LD 3 watt $\mathrm{x} 60$ lumen $=180$ lumen dan lampu CFL 8 watt $\mathrm{x} 17$ lumens $=136$ lumens. Lampu neon yang digunakan nelayan sebanyak 10 unit $\mathrm{x} 45$ watt $=450$ watt. Lampu nelayan dengan tegangan sebesar 450 watt, maka setara dengan lampu LED 150 watt (1 : 3). Dalam penelitian yang telah dilakukan lampu LED yang telah dibuat sebesar 93 watt dan 29 ampare, maka perlu dilakukan penambahan daya pada lampu LED celup (Setiadi et al. 2012). 


\section{Uji sebaran cahaya di udara}

\section{Uji sebaran cahaya lampu LED celup}

Uji sebaran cahaya dilakukan untuk mengetahui tingkat iluminasi dan pola sebaran cahaya lampu LED yang di buat. Pengukuran intensitas cahaya dilakukan pada 4 jarak yang berbeda yaitu $50 \mathrm{~cm}, 75$ $\mathrm{cm}, 100 \mathrm{~cm}$, dan $125 \mathrm{~cm}$. Pengukuran ini dilakukan secara horizontal dan vertikal dengan kelipatan sudut $10^{\circ}$ pada medium udara. Ilustrasi pengukuran iluminasi cahaya pada lampu LED celup terdapat pada Gambar 7.

Pengukuran hanya dilakukan pada 2 sisi lampu dengan sudut yang di ambil $0^{\circ}-180^{\circ}$ dan untuk sudut $180^{\circ}-360^{\circ}$ dianggap sama nilainya, baik pengukuran secara horizontal maupun vertikal. Hal ini dipengaruhi oleh bentuk desain konstruksi lampu yang berbentuk tabung atau silinder vertikal dan jenis maupun jumlah lampu yang digunakan sama. Pola sebaran cahaya dan pola penurunan intensitas cahaya lampu LED celup posisi horizontal dan vertikal terdapat pada Gambar 8 dan 9.

Hasil dari pengukuran intensitas cahaya secara horizontal berdasarkan jarak yang berbeda yaitu pada jarak 50 $\mathrm{cm}$ berkisar antara 95-97 lux, jarak 75 $\mathrm{cm}$ berkisar antara 66-69 lux, jarak 100 $\mathrm{cm}$ berkisar antara 46-49 lux, dan jarak $125 \mathrm{~cm}$ berkisar antara 27-29 lux. Bentuk pola sebaran cahaya secara horizontal adalah berbentuk bulat. Hasil pengukuran intensitas cahaya secara vertikal yaitu pada jarak $50 \mathrm{~cm}$ berkisar antara 15-136 lux, jarak $75 \mathrm{~cm}$ berkisar antara 6-107 lux, jarak $100 \mathrm{~cm}$ berkisar antara 3-80 lux, dan jarak $125 \mathrm{~cm}$ berkisar antara 2-62 lux. Bentuk pola sebaran cahaya secara vertikal seperti kupu-kupu tapi agak setengah kerucut kebawah. Diantara kedua sisi tidak mengalami penurunan iluminasi cahaya yang signifikan. Data iluminasi cahaya dan nilai persamaan eksponensial lampu LED celup terdapat pada Tabel 1 dan 2 .

\section{Uji sebaran cahaya pada lampu neon}

Uji sebaran cahaya pada lampu neon juga dilakukan dengan cara yang sama seperti pada lampu LED celup. Hasil dari pengukuran iluminasi cahaya pada sisi horizontal berdasarkan jarak yang berbeda yaitu pada jarak $50 \mathrm{~cm}$ berkisar antara 997999 lux, jarak $75 \mathrm{~cm}$ berkisar antara 463465 lux, jarak $100 \mathrm{~cm}$ berkisar 276-278 lux, dan jarak $125 \mathrm{~cm}$ berkisar 178-180 lux. Bentuk pola sebaran cahaya pada sisi horizontal adalah bulat. Sedangkan, hasil pengukuran iluminasi cahaya pada sisi vertikal yaitu pada jarak $50 \mathrm{~cm}$ berkisar 88928 lux, jarak $75 \mathrm{~cm}$ berkisar 50-434 lux, jarak $100 \mathrm{~cm}$ berkisar antara 28-258 lux, dan jarak $125 \mathrm{~cm}$ berkisar 18-168 lux. Bentuk pola sebaran cahaya pada sisi vertikal seperti kupu-kupu tapi tidak mengerucut kebawah. Diantara kedua sisi mengalami penurunan nilai iluminasi cahaya yang signifikan. Ilustrasi pengukuran iluminasi cahaya pada lampu neon terdapat pada Gambar 10 dan pola sebaran cahaya serta pola penurunan intensitas cahaya lampu neon posisi horizontal dan vertikal terdapat pada Gambar 11 dan 12. Sedangkan data iluminasi cahaya dan nilai eksponensial lampu neon terdapat pada Tabel 3 dan 4.

\section{Daya tahan accu terhadap lampu LED celup}

Perhitungan terkait berapa lama waktu tahan accu dapat membackup lampu LED celup. Perhitungan ini sangat diperlukan untuk mengetahui berapa lama waktu accu bertahan pada saat digunakan pada saat operasi penangkapan ikan berdasarkan besar sumber daya beban yang digunakan. Spesifikasi accu yang digunakan dengan sumber daya $12 \mathrm{~V} 120$ Ah dan beban daya lampu LED sebesar 93 Watt. Untuk menghitung berapa lama daya tahan accu terhadap beban berdasarkan persamaan dibawah ini (Zunelfi 2012), yaitu : $\mathrm{V}_{\mathrm{LED}}: 3.2$ $-3.4 \mathrm{~V} ; \mathrm{R}_{\mathrm{LED}}$ : $44 \mathrm{Ohm} 47 \mathrm{Ohm}$; Daya accu : $12 \mathrm{~V} 120$ Ah; $\mathrm{I}_{\mathrm{LED}}$ : 29 Ampare; dan $\mathrm{P}_{\mathrm{LED}}$ : 93 watt.

$$
\begin{gathered}
\mathrm{I}_{\text {accu }}=\frac{P_{L E D}}{V_{a c c u}}=\mathrm{A} \\
\mathrm{t}_{\text {accu }}=\frac{A h_{L E D}}{I_{\text {accu }}} \\
\mathrm{t}_{\text {hasil }}=t_{\text {accu }}-3 \mathrm{Jam} \text { (faktor diefesiensi); atau } \\
\mathrm{P}_{\text {accu }}=V_{\text {accu }} \times \text { A } h_{\text {accu }}=\frac{\text { Watt }}{\text { Hours }} \\
\mathrm{t}_{\text {accu }}=\frac{\left(\frac{\text { Watt }}{\text { Hours }}\right)}{\text { Watt }}=\text { Hours } \\
\mathrm{t}=t_{\text {accu }}-3 \text { jam (faktor diefesiensi) }
\end{gathered}
$$

Keterangan :

$\mathrm{I}_{\text {accu }}$ : Arus accu (A), $P_{L E D}$ : Daya LED (W), $V_{\text {accu }}^{\text {accu }}$ : Tegangan sumber $(\mathrm{V})$, 
$\mathrm{t}_{\text {accu }}$ : Daya tahan aki

$\mathrm{P}_{\text {accu }}$ : Daya accu $(\mathrm{Wh})$

Hasil perhitungan daya tahan aki terhadap beban didapatkan hasil, akibertahan selama 12.48 jam/menit. Dari hasil perhitungan maka nelayan cukup untuk digunakan selama satu malam. Untuk penangkapan malam berikutnya nelayan cukup mengecas kembali accu tersebut.

\section{Penelitian di lapangan}

Proses operasi penangkapan ikan

Pengoperasian bagan apung dibutuhkan 3 orang ABK yang dipimpin oleh satu orang juragan laut (nahkoda). Juragan laut memimpin dan bertanggung jawab terhadap seluruh operasi penangkapan ikan. Waktu penangkapan dibagi dalam 2 tahap yaitu dari pukul 19.30-00.30 WIB dan 00.30-05.30 WIB. Jumlah hauling dalam 1 malam sebanyak 4 kali hauling. Ilustrasi metode penangkapan ikan dan waktu proses penangkapan ikan terdapat pada Gambar 13 dan Tabel 5.

\section{Hasil tangkapan bagan apung}

Jumlah dan komposisi jenis hasil tangkapan dengan menggunakan alat bantu lampu LED celup dan lampu neon adalah teri (Stolephorous sp), peperek (Leiognathus $s p$ ), tembang (Sardinella sp), selar (selar sp), kembung (Rastrelliger $s p$ ), japuh (Dussumeriea sp), layur (Trichiurus $s p$ ), cumi-cumi (Loligo $s p$ ), julung-julung (Hemirhamphus $s p$ ), layang (Decapterus $s p$ ), terbang (Cypsilurus sp), bawal (Formio sp), dan rambeng (Dipterygonous $s p$ ).

Jenis ikan dominan yang tertangkap dengan lampu LED adalah teri (Stolephorous $s p)$, peperek (Leiognathus $s p$ ), tembang (Sardinella $s p$ ), kembung (Rasrelliger $s p$ ), selar (Selar $s p$ ), japuh (Dussumeriea $s p$ ), dan layur (Trichiurus sp), jumlah total tangkapan sebanyak $3779 \mathrm{~kg}$ dengan rata-rata tangkapan sebesar 377.9kg/trip. Sedangkan jenis ikan dominan yang tertangkap dengan lampu neon adalah teri (Stolephorous $s p)$, peperek (Leiognathus $s p$ ), tembang (Sardinella $s p$ ), selar (Selar $s p$ ), kembung (Rastrelliger $s p$ ), japuh (Dussumeriea $s p$ ), dan layur (Trichiurus sp), jumlah total 2343 dengan rata-rata tangkapan adalah 234.3 $\mathrm{kg} /$ trip selama 10 trip. Hasil tangkapan bagan apung dengan menggunakan lampu LED celup dan neon terdapat pada Gambar 14,15,16,17 dan Tabel 6, 7 .

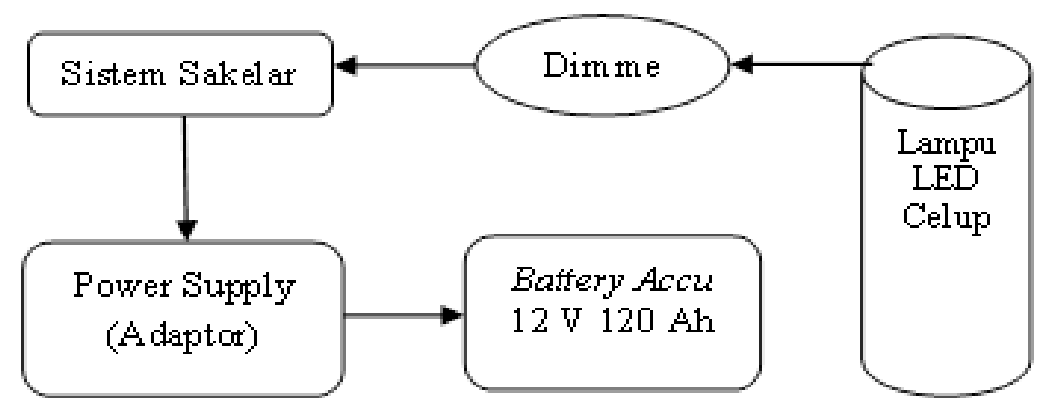

Gambar 4. Sistem rangkaian pada lampu LED celup

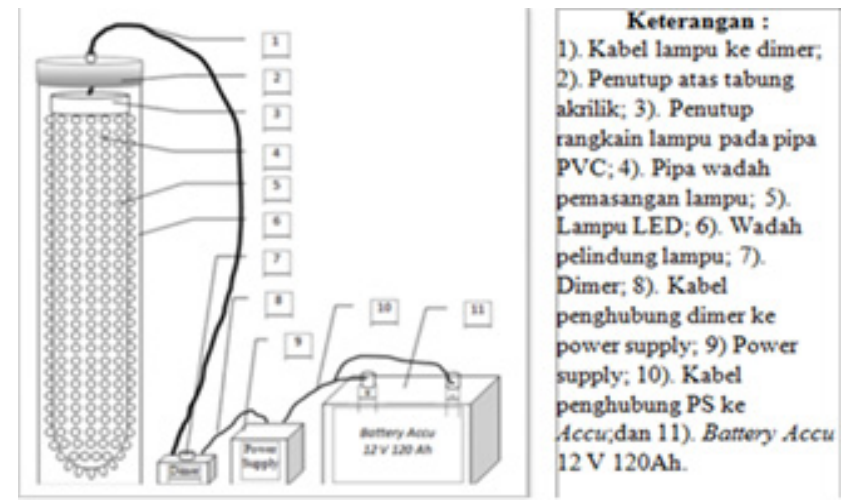

Gambar 5. Bentuk konstruksi lampu LED celup 


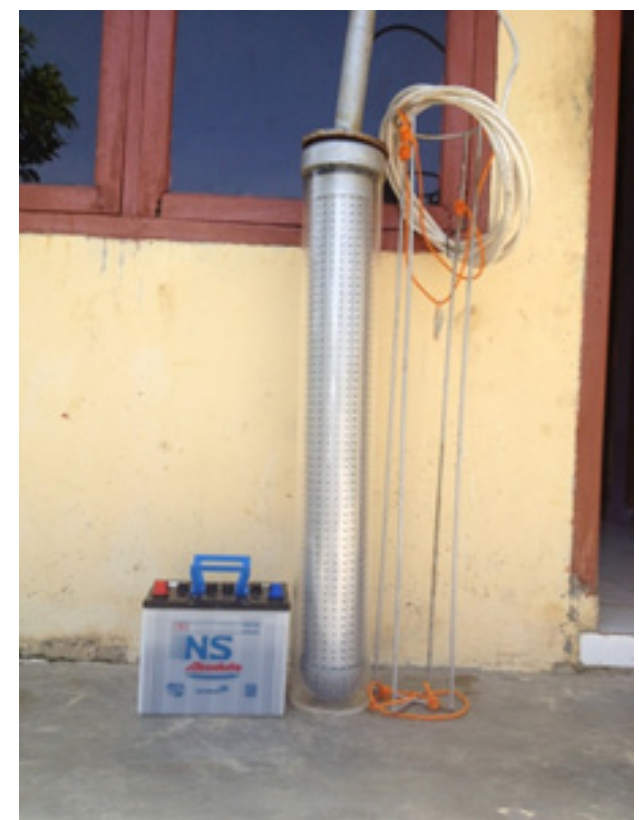

Gambar 6. Hasil konstruksi lampu LED celup

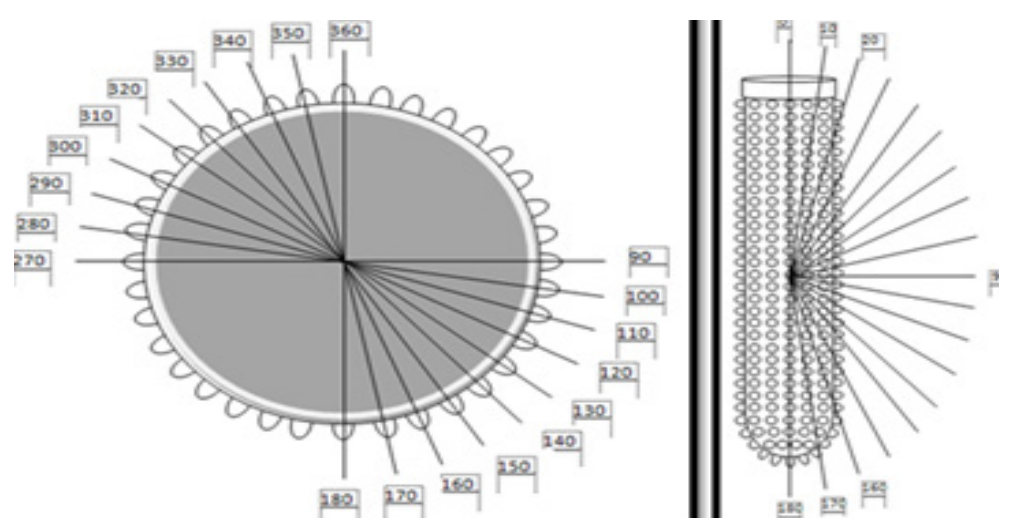

Gambar 7. Ilustrasi pengukuran iluminasi cahaya pada lampu LED celup a. Posisi horizontal; b. posisi vertikal

\section{Posisi Horizontal $-360^{\circ}$}

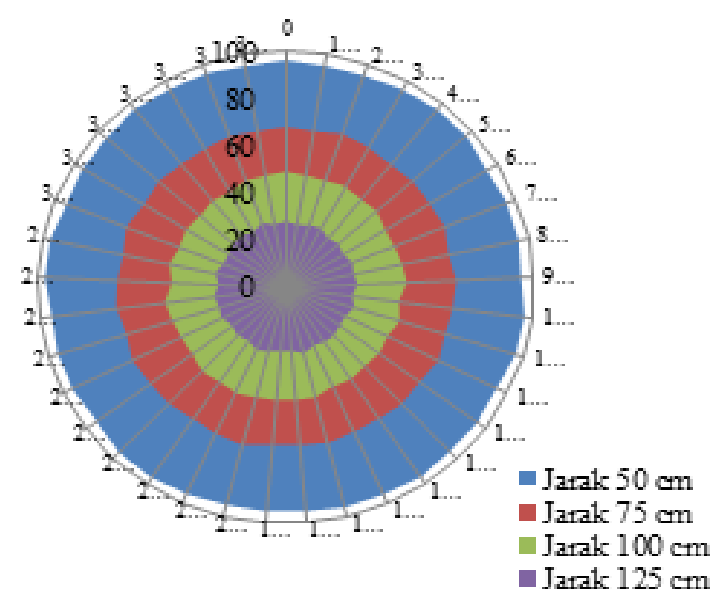

Posisi Vertikal $-360^{\circ}$

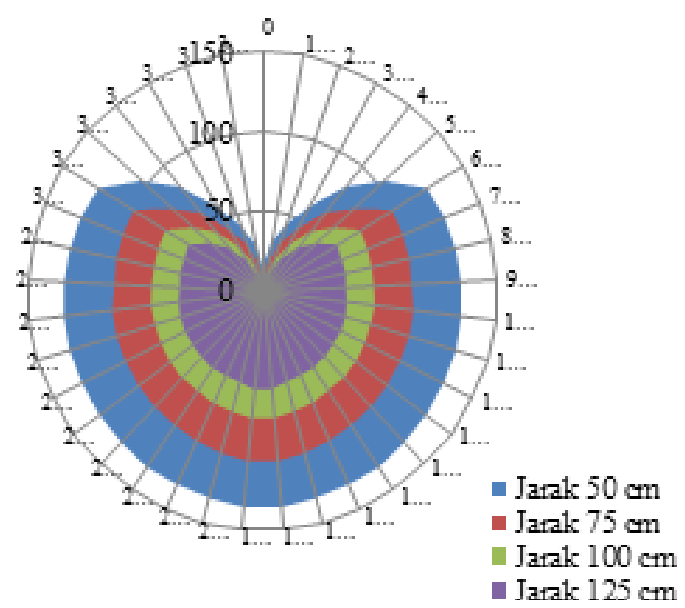

Gambar 8. Pola sebaran cahaya lampu LED celup 

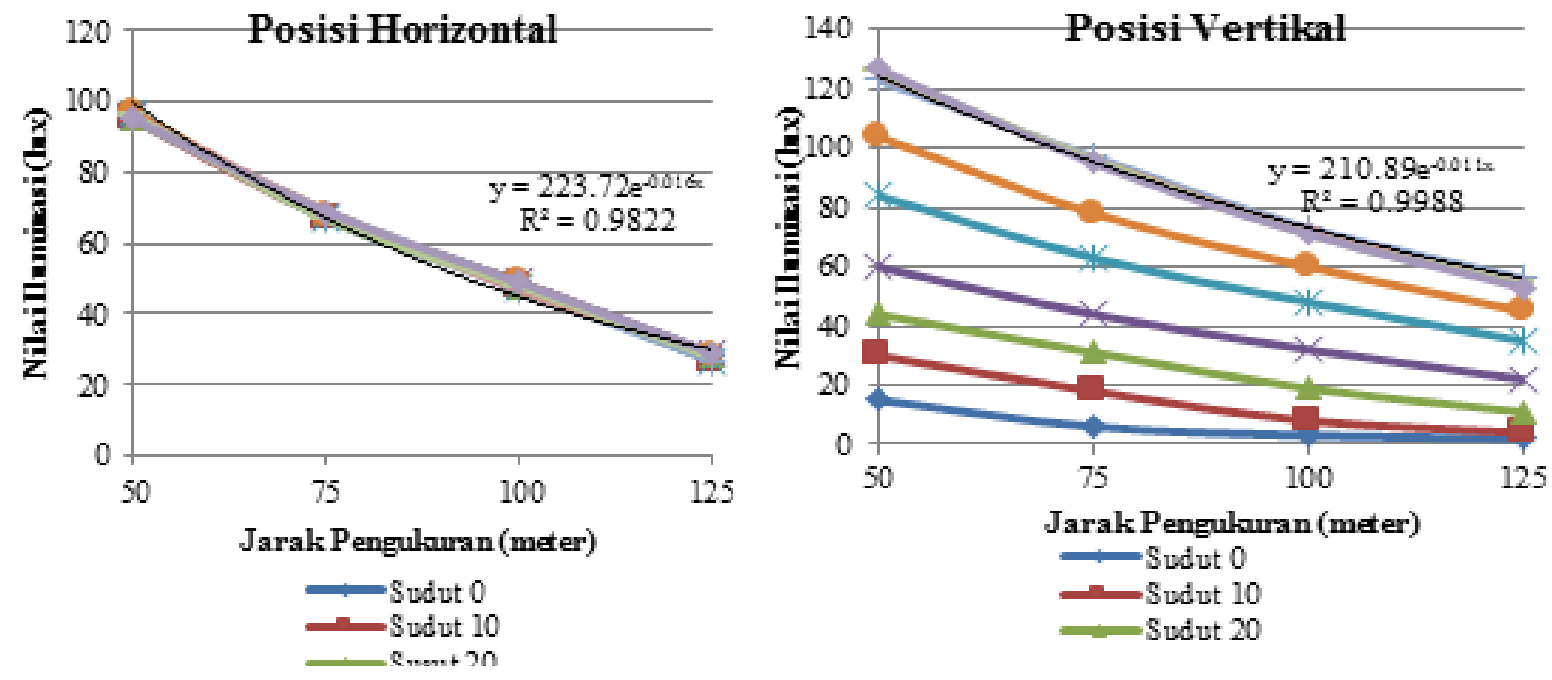

Gambar 9. Pola penurunan intensitas cahaya pada lampu LED celup

Tabel 1. Data iluminasi cahaya lampu LED celup

\begin{tabular}{|c|c|c|c|c|c|c|c|c|c|}
\hline \multicolumn{5}{|c|}{ Nilai Iluminasi Posisi Horizontal $(L u x)$} & \multicolumn{5}{|c|}{ Nilai Iluminasi Posisi Vertikal ( $L u x)$} \\
\hline $\begin{array}{c}\text { Sudut } \\
\left.\text { ( }{ }^{\circ}\right)\end{array}$ & $50 \mathrm{~cm}$ & $75 \mathrm{~cm}$ & $100 \mathrm{~cm}$ & $125 \mathrm{~cm}$ & $\begin{array}{c}S u d u t \\
\left({ }^{\circ}\right)\end{array}$ & $50 \mathrm{~cm}$ & $75 \mathrm{~cm}$ & $100 \mathrm{~cm}$ & $125 \mathrm{~cm}$ \\
\hline 0 & 96 & 68 & 49 & 28 & 0 & 15 & 6 & 3 & 2 \\
\hline 10 & 95 & 67 & 48 & 27 & 10 & 30 & 18 & 8 & 4 \\
\hline 20 & 95 & 69 & 48 & 28 & 20 & 44 & 31 & 19 & 11 \\
\hline 30 & 96 & 68 & 49 & 29 & 30 & 60 & 44 & 32 & 22 \\
\hline 40 & 97 & 67 & 48 & 27 & 40 & 84 & 63 & 48 & 35 \\
\hline 50 & 97 & 68 & 49 & 28 & 50 & 104 & 78 & 60 & 45 \\
\hline 60 & 95 & 68 & 47 & 27 & 60 & 123 & 97 & 73 & 56 \\
\hline 70 & 96 & 69 & 47 & 29 & 70 & 125 & 96 & 72 & 54 \\
\hline 80 & 96 & 67 & 48 & 28 & 80 & 126 & 96 & 71 & 54 \\
\hline 90 & 95 & 69 & 49 & 29 & 90 & 127 & 95 & 71 & 53 \\
\hline 100 & 97 & 68 & 46 & 27 & 100 & 128 & 97 & 72 & 54 \\
\hline 110 & 97 & 67 & 48 & 29 & 110 & 129 & 98 & 72 & 55 \\
\hline 120 & 95 & 69 & 46 & 27 & 120 & 129 & 98 & 73 & 56 \\
\hline 130 & 96 & 67 & 47 & 27 & 130 & 130 & 99 & 74 & 56 \\
\hline 140 & 96 & 68 & 46 & 28 & 140 & 131 & 100 & 75 & 57 \\
\hline 150 & 97 & 67 & 47 & 28 & 150 & 133 & 101 & 75 & 58 \\
\hline 160 & 96 & 67 & 46 & 27 & 160 & 133 & 103 & 77 & 58 \\
\hline 170 & 96 & 68 & 48 & 29 & 170 & 134 & 105 & 78 & 59 \\
\hline 180 & 95 & 67 & 48 & 27 & 180 & 136 & 107 & 80 & 62 \\
\hline
\end{tabular}


Tabel 2. Nilai persamaan eksponensial lampu LED celup

\begin{tabular}{ccc}
\hline Sudut $\left({ }^{\circ}\right)$ & $\begin{array}{c}\text { Persamaan Eksponensial } \\
\text { (Horizontal) }\end{array}$ & $\begin{array}{c}\text { Persamaan Eksponensial } \\
\text { (Vertical) }\end{array}$ \\
\hline 0 & $\mathrm{y}=223.7 \mathrm{e}-0.01 \mathrm{x}$ & $\mathrm{y}=50.96 \mathrm{e}^{-0.02 \mathrm{x}}$ \\
10 & $\mathrm{y}=225.6 \mathrm{e}-0.01 \mathrm{x}$ & $\mathrm{y}=126.3 \mathrm{e}^{-0.02 \mathrm{x}}$ \\
20 & $\mathrm{y}=223.1 \mathrm{e}-0.01 \mathrm{x}$ & $\mathrm{y}=117.5 \mathrm{e}^{-0.01 \mathrm{x}}$ \\
30 & $\mathrm{y}=217.5 \mathrm{e}-0.01 \mathrm{x}$ & $\mathrm{y}=118.3 \mathrm{e}^{-0.01 \mathrm{x}}$ \\
40 & $\mathrm{y}=231.8 \mathrm{e}-0.01 \mathrm{x}$ & $\mathrm{y}=150.5 \mathrm{e}^{-0.01 \mathrm{x}}$ \\
50 & $\mathrm{y}=226.7 \mathrm{e}-0.01 \mathrm{x}$ & $\mathrm{y}=180.7 \mathrm{e}^{-0.01 \mathrm{x}}$ \\
60 & $\mathrm{y}=228.1 \mathrm{e}-0.01 \mathrm{x}$ & $\mathrm{y}=210.8 \mathrm{e}^{-0.01 \mathrm{x}}$ \\
70 & $\mathrm{y}=220.3 \mathrm{e}-0.01 \mathrm{x}$ & $\mathrm{y}=220.6 \mathrm{e}^{-0.01 \mathrm{x}}$ \\
80 & $\mathrm{y}=222.2 \mathrm{e}-0.01 \mathrm{x}$ & $\mathrm{y}=223.2 \mathrm{e}^{-0.01 \mathrm{x}}$ \\
90 & $\mathrm{y}=216.4 \mathrm{e}-0.01 \mathrm{x}$ & $\mathrm{y}=227.5 \mathrm{e}^{-0.01 \mathrm{x}}$ \\
\hline
\end{tabular}

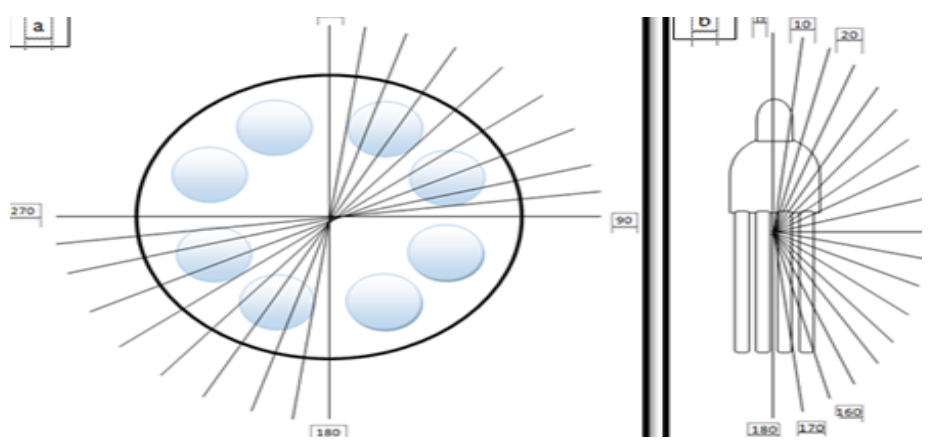

Gambar 10. Ilustrasi pengukuran iluminasi cahaya pada lampu neon a. Posisi horizontal; b. posisi vertikal
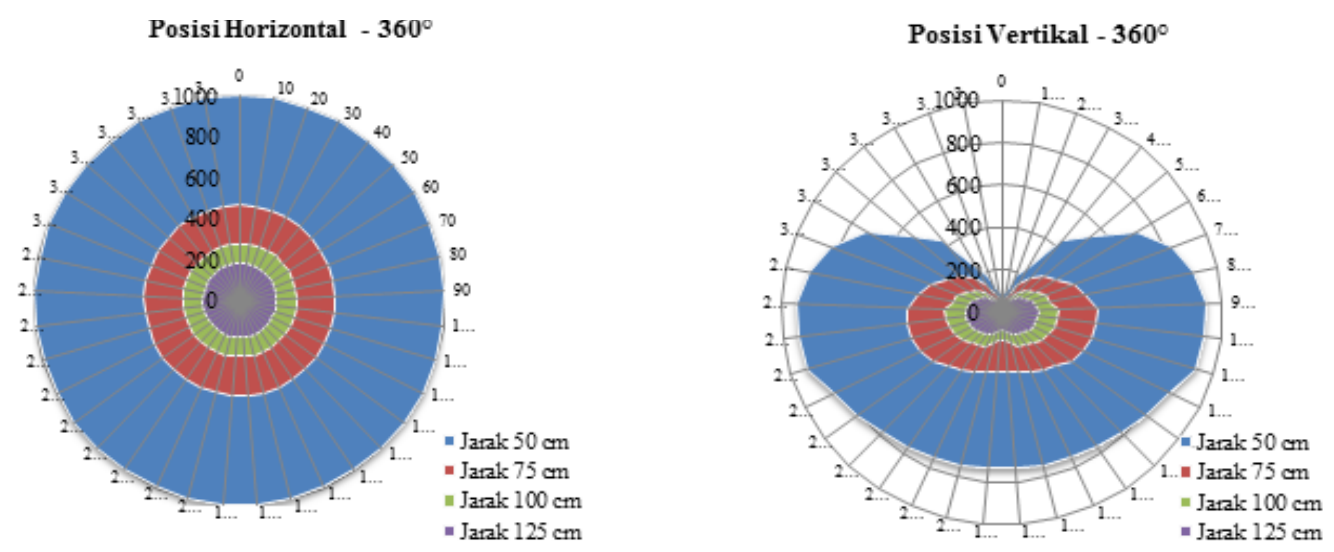

Gambar 11. Pola sebaran cahaya lampu neon

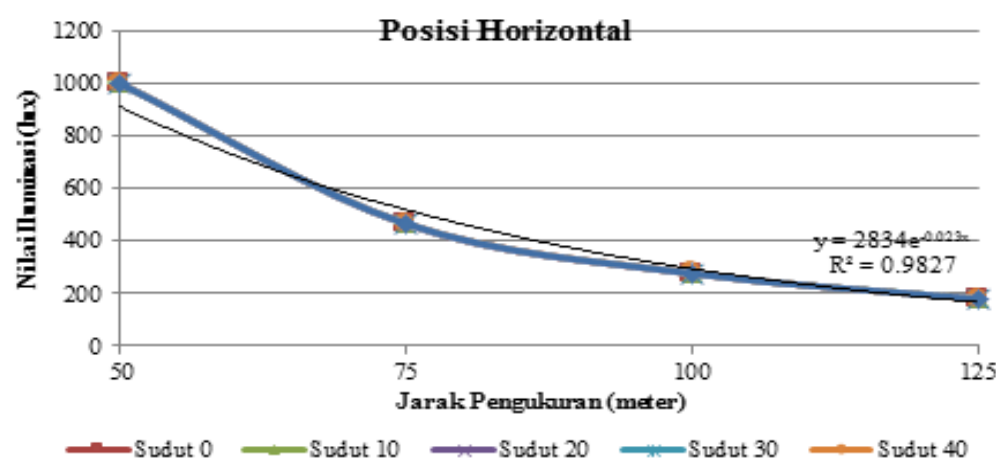




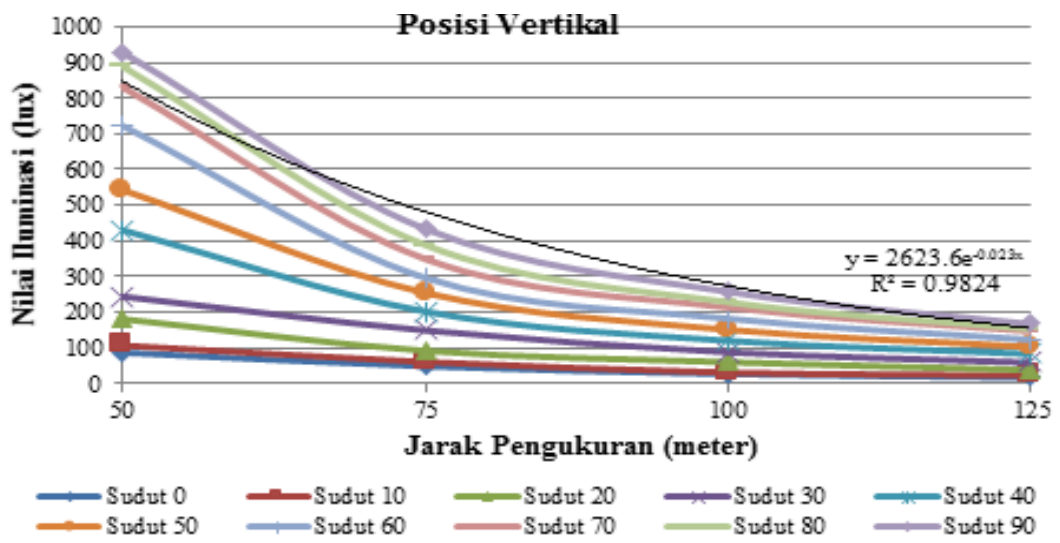

Gambar 12. Pola penurunan intensitas cahaya lampu neon, atas: posisi Horizontal, bawah: posisi Vertikal

Tabel 3. Data iluminasi cahaya lampo neon

\begin{tabular}{cccccccccc}
\hline \multicolumn{3}{c}{ Nilai Iluminasi Posisi Horizontal (Lux) } & \multicolumn{5}{c}{ Nilai Iluminasi Posisi Vertikal (Lux) } \\
\hline $\begin{array}{c}\text { S u d u t } \\
(\mathbf{O})\end{array}$ & $\mathbf{5 0} \mathbf{~ c m}$ & $\mathbf{7 5} \mathbf{~ c m}$ & $\mathbf{1 0 0} \mathbf{~ c m}$ & $\mathbf{1 2 5} \mathbf{~ c m}$ & $\begin{array}{c}\mathbf{S ~ u ~ d ~ u ~ t ~} \\
\mathbf{(} \mathbf{)})\end{array}$ & $\mathbf{5 0} \mathbf{~ c m}$ & $\mathbf{7 5} \mathbf{~ c m}$ & $\mathbf{1 0 0} \mathbf{~ c m}$ & $\mathbf{1 2 5} \mathbf{~ c m}$ \\
$\mathbf{0}$ & 998 & 463 & 275 & 179 & $\mathbf{0}$ & 88 & 50 & 28 & 18 \\
$\mathbf{1 0}$ & 999 & 464 & 276 & 179 & $\mathbf{1 0}$ & 108 & 62 & 32 & 24 \\
$\mathbf{2 0}$ & 997 & 463 & 276 & 180 & $\mathbf{2 0}$ & 182 & 93 & 61 & 39 \\
$\mathbf{3 0}$ & 998 & 464 & 277 & 180 & $\mathbf{3 0}$ & 245 & 150 & 89 & 60 \\
$\mathbf{4 0}$ & 998 & 466 & 278 & 178 & $\mathbf{4 0}$ & 431 & 203 & 121 & 84 \\
$\mathbf{5 0}$ & 999 & 465 & 278 & 179 & $\mathbf{5 0}$ & 543 & 255 & 152 & 104 \\
$\mathbf{6 0}$ & 999 & 465 & 277 & 180 & $\mathbf{6 0}$ & 723 & 297 & 183 & 124 \\
\hline
\end{tabular}

Tabel 3. Data iluminasi cahaya lampo neon

\begin{tabular}{cccccccccc}
\hline \multicolumn{3}{c}{ Nilai Iluminasi Posisi Horizontal (Lux) } & \multicolumn{5}{c}{ Nilai Iluminasi Posisi Vertikal (Lux) } \\
\hline $\begin{array}{c}\mathbf{S ~ u ~ d ~ u ~ t ~} \\
(\mathbf{0})\end{array}$ & $\mathbf{5 0} \mathbf{~ c m}$ & $\mathbf{7 5} \mathbf{~ c m}$ & $\mathbf{1 0 0} \mathbf{~ c m}$ & $\mathbf{1 2 5} \mathbf{~ c m}$ & $\mathbf{S ~ u ~ d ~ u ~ t ~}$ & $\mathbf{5 0} \mathbf{~ c m}$ & $\mathbf{7 5} \mathbf{~ c m}$ & $\mathbf{1 0 0} \mathbf{~ c m}$ & $\mathbf{1 2 5} \mathbf{~ c m}$ \\
$\mathbf{7 0}$ & 998 & 464 & 276 & 180 & $\mathbf{7 0}$ & 831 & 350 & 214 & 148 \\
$\mathbf{8 0}$ & 998 & 463 & 275 & 179 & $\mathbf{8 0}$ & 889 & 389 & 229 & 154 \\
$\mathbf{9 0}$ & 997 & 465 & 276 & 179 & $\mathbf{9 0}$ & 928 & 434 & 258 & 168 \\
$\mathbf{1 0 0}$ & 998 & 465 & 276 & 180 & $\mathbf{1 0 0}$ & 923 & 429 & 250 & 164 \\
$\mathbf{1 1 0}$ & 998 & 466 & 277 & 179 & $\mathbf{1 1 0}$ & 918 & 426 & 248 & 158 \\
$\mathbf{1 2 0}$ & 999 & 463 & 277 & 179 & $\mathbf{1 2 0}$ & 851 & 410 & 237 & 155 \\
$\mathbf{1 3 0}$ & 998 & 465 & 276 & 178 & $\mathbf{1 3 0}$ & 814 & 392 & 220 & 145 \\
$\mathbf{1 4 0}$ & 998 & 465 & 276 & 178 & $\mathbf{1 4 0}$ & 780 & 350 & 197 & 134 \\
$\mathbf{1 5 0}$ & 999 & 464 & 275 & 179 & $\mathbf{1 5 0}$ & 762 & 331 & 188 & 123 \\
$\mathbf{1 6 0}$ & 998 & 465 & 276 & 179 & $\mathbf{1 6 0}$ & 751 & 310 & 177 & 117 \\
$\mathbf{1 7 0}$ & 998 & 465 & 277 & 180 & $\mathbf{1 7 0}$ & 746 & 290 & 152 & 97 \\
$\mathbf{1 8 0}$ & 999 & 466 & 276 & 180 & $\mathbf{1 8 0}$ & 740 & 278 & 135 & 86 \\
\hline
\end{tabular}


Tabel 4. Nilai persamaan eksponensial lampu neon

\begin{tabular}{ccc}
\hline Sudut $\left({ }^{\circ}\right)$ & $\begin{array}{c}\text { Persamaan Eksponensial } \\
\text { (Horizontal) }\end{array}$ & $\begin{array}{c}\text { Persamaan Eksponensial } \\
\text { (Vertical) }\end{array}$ \\
\hline 0 & $\mathrm{y}=2831 \cdot \mathrm{e}^{-0.02 x}$ & $\mathrm{y}=291.2 \mathrm{e}^{-0.02 x}$ \\
10 & $\mathrm{y}=2837 \cdot \mathrm{e}^{-0.02 x}$ & $\mathrm{y}=291.2 \mathrm{e}^{-0.02 x}$ \\
20 & $\mathrm{y}=2814 \cdot \mathrm{e}^{-0.02 x}$ & $\mathrm{y}=465 \cdot 3 \mathrm{e}^{-0.02 x}$ \\
30 & $\mathrm{y}=2820 \cdot \mathrm{e}^{-0.02 x}$ & $\mathrm{y}=6224 \cdot \mathrm{e}^{-0.01 x}$ \\
40 & $\mathrm{y}=2852 \cdot \mathrm{e}^{-0.02 x}$ & $\mathrm{y}=1152 \cdot \mathrm{e}^{-0.02 x}$ \\
50 & $\mathrm{y}=2839 \cdot \mathrm{e}^{-0.02 x}$ & $\mathrm{y}=1470 \cdot \mathrm{e}^{-0.02 x}$ \\
60 & $\mathrm{y}=2827 \cdot \mathrm{e}^{-0.02 x}$ & $\mathrm{y}=1993 \cdot \mathrm{e}^{-0.02 x}$ \\
70 & $\mathrm{y}=2821 \cdot \mathrm{e}^{-0.02 x}$ & $\mathrm{y}=2252 \cdot \mathrm{e}^{-0.02 x}$ \\
80 & $\mathrm{y}=2831 \cdot \mathrm{e}^{-0.02 x}$ & $\mathrm{y}=2520 \cdot \mathrm{e}^{-0.02 x}$ \\
90 & $\mathrm{y}=2834 \cdot \mathrm{e}^{-0.02 x}$ & $\mathrm{y}=2623 \cdot \mathrm{e}^{-0.02 x}$ \\
\hline
\end{tabular}
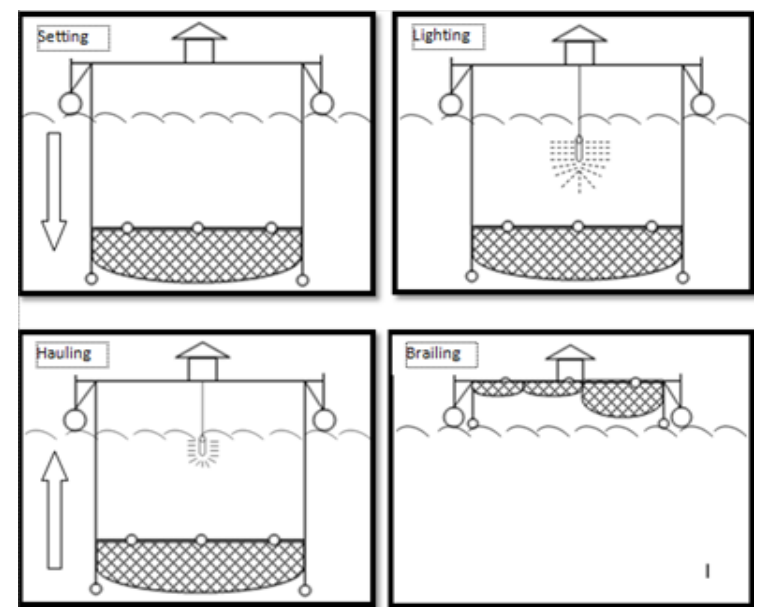

Gambar 13. Ilustrasi metode penangkapan ikan

Tabel 4. Nilai persamaan eksponensial lampu neon

\begin{tabular}{clc}
\hline No. & \multicolumn{1}{c}{ Deskripsi } & Waktu yang dibutuhkan (menit) \\
\hline 1 & Persiapan, penurunan jaring & $10-15$ menit \\
2 & Pencahayaan dan pengamatan : & $90-120$ menit \\
& a. Lampu celup & $120-180$ menit \\
& b. Lampu neon & $20-30$ menit \\
3 & Pemadaman secara bertahap : & Langsung dengan lampu hauling \\
& a. Lampu celup & $10-20$ menit \\
4 & b. Lampu neon & $10-15$ menit \\
5 & Pengangkan jaring & $10-15$ menit \\
6 & Mengiring ikan ke sisi kapal & $20-90$ menit \\
7 & Sortir
\end{tabular}



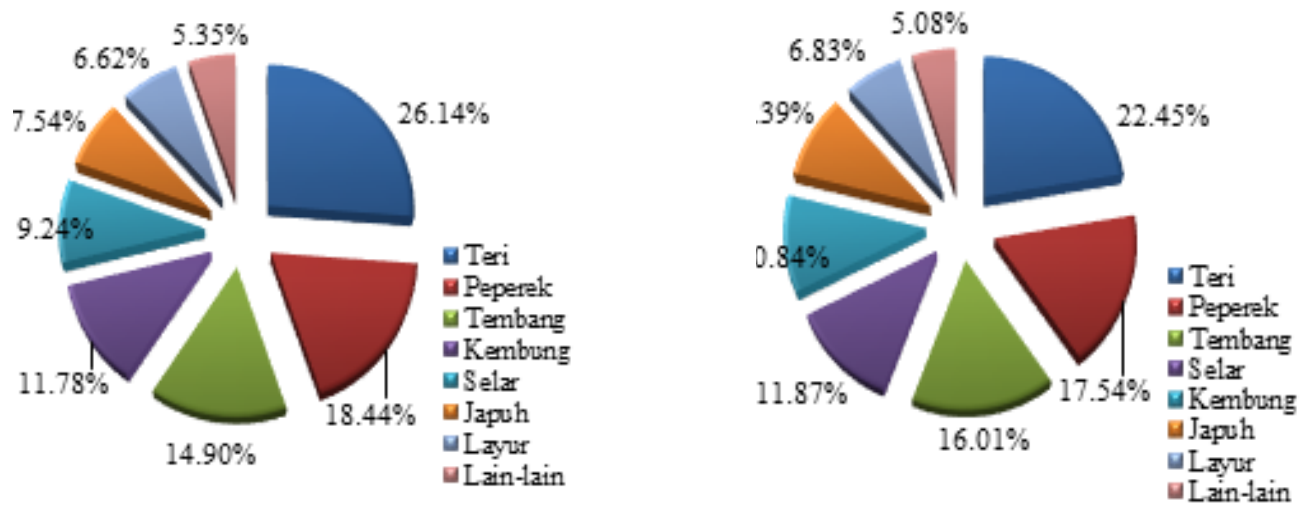

Gambar 14. Hasil tangkapan dengan lampu LED celup (a) dan lampu neon (b)

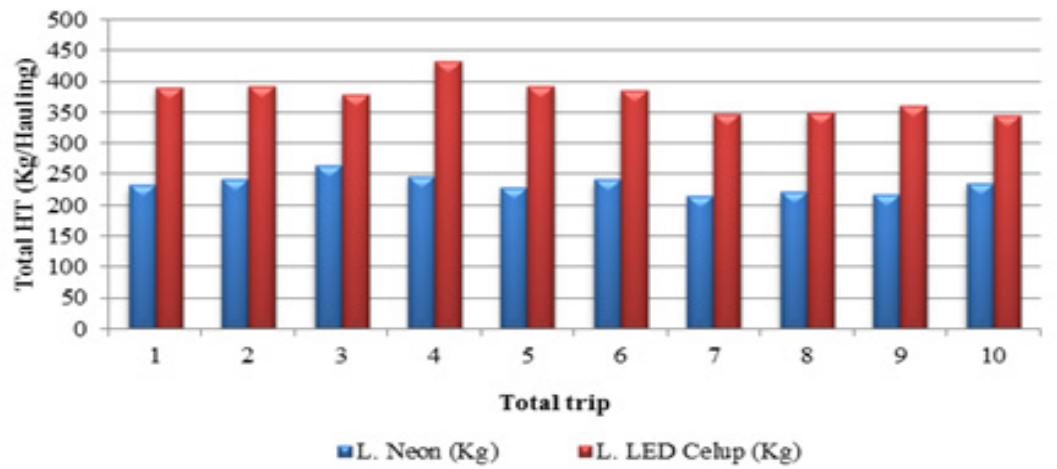

Gambar 15. Total hasil tangkapan pertrip

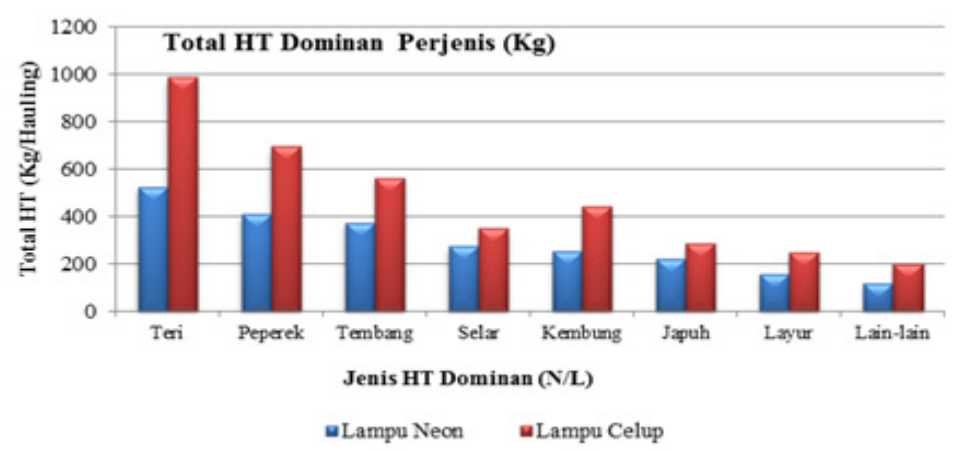

Gambar 16. Perbandingan hasil tangkapan ikan dominan lampu LED celup dengan lampu neon

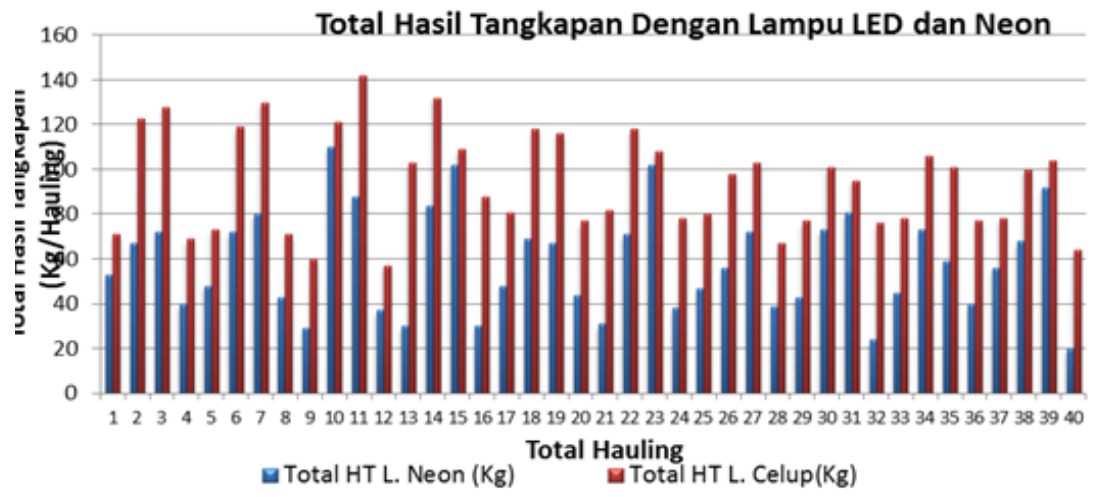

Gambar 17. Total hasil tangkapan dengan lampu LED celup dan lampu neon 
Tabel 6. Hasil tangkapan bagan apung dengan lampu neon

\begin{tabular}{|c|c|c|c|c|c|c|c|}
\hline \multirow[t]{2}{*}{ No } & \multirow[t]{2}{*}{ Nama Ikan } & \multicolumn{4}{|c|}{$\begin{array}{c}\text { Hasil Tangkapan } \\
\text { Perhauling (Kg) }\end{array}$} & \multicolumn{2}{|c|}{$\begin{array}{l}\text { Total Hasil Tangkapan } \\
\text { Ikan }\end{array}$} \\
\hline & & 1 & 2 & 3 & 4 & (kg) & $(\%)$ \\
\hline 1 & Teri & 103 & 149 & 152 & 122 & 526 & $22.45 \%$ \\
\hline 2 & Peperek & 66 & 131 & 125 & 89 & 411 & $17.54 \%$ \\
\hline 3 & Tembang & 71 & 109 & 115 & 80 & 375 & $16.01 \%$ \\
\hline 4 & Selar & 59 & 75 & 77 & 67 & 278 & $11.87 \%$ \\
\hline 5 & Kembung & 43 & 76 & 89 & 46 & 254 & $10.84 \%$ \\
\hline 6 & Japuh & 39 & 70 & 79 & 32 & 220 & $9.39 \%$ \\
\hline 7 & Layur & 34 & 40 & 48 & 38 & 160 & $6.83 \%$ \\
\hline 8 & Lain-lain & 23 & 30 & 39 & 27 & 119 & $5.08 \%$ \\
\hline & & & & & & 2343 & $100.00 \%$ \\
\hline
\end{tabular}

Tabel 6. Hasil tangkapan bagan apung dengan lampu neon

\begin{tabular}{|c|c|c|c|c|c|c|c|}
\hline \multirow[t]{2}{*}{ No } & \multirow[t]{2}{*}{ Nama Ikan } & \multicolumn{4}{|c|}{$\begin{array}{l}\text { Hasil Tangkapan } \\
\text { Perhauling (Kg) }\end{array}$} & \multicolumn{2}{|c|}{$\begin{array}{l}\text { Total Hasil Tangkapan } \\
\text { Ikan }\end{array}$} \\
\hline & & 1 & 2 & 3 & 4 & (kg) & (\%) \\
\hline 1 & Teri & 223 & 266 & 283 & 216 & 988 & $26.14 \%$ \\
\hline 2 & Peperek & 163 & 211 & 209 & 114 & 697 & $18.44 \%$ \\
\hline 3 & Tembang & 118 & 183 & 169 & 93 & 563 & $14.89 \%$ \\
\hline 4 & Kembung & 98 & 130 & 139 & 78 & 445 & $11.78 \%$ \\
\hline 5 & Selar & 79 & 103 & 97 & 70 & 349 & $9.24 \%$ \\
\hline 6 & Japuh & 51 & 99 & 87 & 48 & 285 & $7.54 \%$ \\
\hline 7 & Layur & 44 & 88 & 79 & 39 & 250 & $6.62 \%$ \\
\hline 8 & Lain-lain & 46 & 55 & 62 & 39 & 202 & $5.35 \%$ \\
\hline \multicolumn{6}{|c|}{ Total } & 3779 & $100.00 \%$ \\
\hline
\end{tabular}

KESIMPULAN DAN SARAN

\section{Kesimpulan}

Kesimpulan yang dapat diambil dalam penelitian yang telah dilakukan adalah sebagai berikut desain dan konstruksi lampu LED celup yang berbentuk tabung atau silinder vertikal, efektif sebagai alat bantu pengumpul ikan pelagis kecil pada bagan apung di perairan Patek, Kabupaten Aceh Jaya. Total hasil tangkapan total dengan lampu LED celup sebanyak $3779 \mathrm{~kg}$ dan lampu neon sebanyak $2343 \mathrm{~kg}$, ratarata tangkapan dengan lampu LED celup sebesar $377.90 \mathrm{~kg} /$ trip dan lampu neon sebesar $234.30 \mathrm{~kg} /$ trip, dan komposisi tangkapan. Pengggunaan lampu LED celup lebih efektif dibandingkan lampu neon.

\section{Saran}

Perlu dirancang lampu LED dengan dimensi yang lebih kecil sehingga lebih ringan dan mudah dalam pengoprasiannya atau bisa dirancang tiang di atas bagan untuk pengangkatan lampu ke atas bagan, selanjutnya perlu dilakukan perancangan konstruksi dan ujicoba dengan variasi warna lampu LED yang berbeda.

\section{DAFTAR PUSTAKA}

Alim A, Imran Z. 2008. Revitalisasi Perikanan Tangkap Propinsi Aceh Pasca Tsunami. Direktur Pengembangan Kelautan dan Perikanan, Badan Rekonstuksi dan Rehabilitasi MD-Nias. Banda Aceh.

Amaral EH, Arnold CH. 1980. Experimental fishing for squid with lights in Nantucket Sound. Marine Technology. 62(18) 
:1093-1099.

Firdawati C. 2011. Pengembangan media interaktif berbasis komputer pada materi luas permukaan dan volume tabung dan kerucut untuk siswa SMP kelas IX. E-Journal. Vol VI:8-11.

Gustaman G, Fauziyah, Insani. 2012. Efektifitas perbedaan warna cahaya lampu terhadap hasil tangkapan bagan tancap di Perairan Sungsang Sumatera Selatan. Maspari Journal. 4 (1):92-102.

Haygreen JG, Bowyer JL. 1993. Forest Product and Wood Science an Introduction. Ames, Iowa : The Iowa State University Press.

Hua LT, Xing J. 2013. Research on LED fishing light. School of Physics and Electrical and Mechanical Engineering, Zunyi Normal College Zunyi, Gui Zhou. China. 5(16) :4148-4141.

Nasruddin. 2009. Pengembangan teknologi penangkapan ikan pelagis besar di Kabupaten Aceh Jaya Nanggroe Aceh Darussalam [Tesis]. Bogor: Institut Pertanian Bogor.

Nielsen H. 2003. African alternative energy solutions has developed a new LED solar fishing light system for Mukene fishermen on Lake Victoria. African Alternative Energy Solutions, Ltd. Kampala, Uganda. 44(3) :128-130.

Nikonorov IVe. 1975. Interaction of Fishing Gear with Fish Aggregations. Israel: Keter Publishing House Jerussalem Ltd.

Notanubun J, Patty W. 2010. Perbedaan Penggunaan Intensitas Cahaya lampu terhadap hasil tangkapan bagan apung di Perairan Selat Rosenberg Kabupaten Maluku Tenggara Kepulauan Kei. Program Studi Pemanfaatan Sumberdaya Perikanan, Fakultas Perikanan dan Ilmu Kelautan, Universitas Surakarta. Solo. Vol VI-3.
Puspito G. 2008. Lampu petromaks : manfaat, kelemahan dan solusinya pada perikanan bagan. Staf Pengajar Fakultas Perikanan dan Ilmu Kelautan, Institut Pertanian Bogor. Bogor.

Sudirman H, Mallawa A. 2004. Teknik Penangkapan Ikan. Rineka Cipta. Jakarta.

Sudirman H, Nessa N. 2011. Perikanan Bagan dan Aspek Pengelolaannya. Malang: UMM Press.

Sugioyono. 2007. Statistik Untuk Penelitian. Bandung: Alfa Beta.

Sulaiman SH. 2010. Model alternatif pengelolaan perikanan berbasis hukum Adat Laot di Kabupaten Aceh Jaya menuju keberkelanjutan lingkungan yang berorientasi kesejahteraan masyarakat [Tesis] Semarang: Universitas Diponegoro.

Setiadi FD, Purnomo DD, Susilo D. 2012. Modul lampu LED (Light Emitting Diode) Program Studi Teknik Elektro, Fakultas Elektronika dan Komputer, Universitas Kristen Setya Wacana. Salatiga. Vol IV:133-134.

Syafrie H. 2012. Efektivitas Lampu Tabung pada Perikanan Bagan [Tesis]. Bogor: Institut Pertanian Bogor.

Thenu IM. 2014. Aplikasi Lampu LED (Light Emitting Diode) pada Pengoperasian Bagan Tancap [Tesis]. Bogor: Institut Pertanian Bogor.

Wardana IS, Warsito A, Karnoto. 2011. Perancangan inverter push pull resonan paralel pada aplikasi fotovoltaik. Jurnal Fisika dan Terapan. Vol 3:188-201.

Yulianto ES. 2015. Rekayasa Unit Lampu LED Bawah Air untuk Riset Tingkah Laku Ikan [Tesis]. Bogor: Institut Pertanian Bogor.

Zunelfi. 2012. Perhitungan lama waktu pemakaian dan pengisian aki. E-Journal. Vol. 3.62-64. 